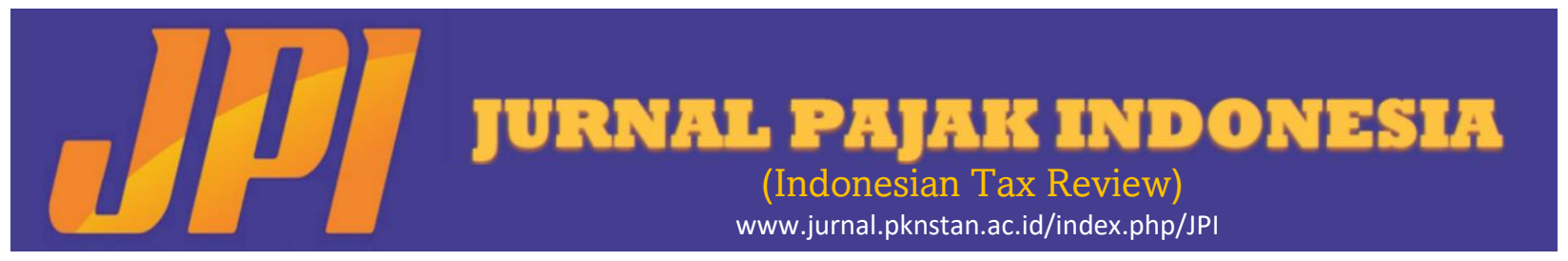

\title{
PENGAWASAN KEPATUHAN PERPAJAKAN WAJIB PAJAK STRATEGIS DI KPP PRATAMA SUKOHARJO
}

\author{
Fanuel Felix Christian \\ Jurusan Pajak, Politeknik Keuangan Negara STAN \\ Irwan Aribowo \\ Jurusan Pajak, Politeknik Keuangan Negara STAN
}

Alamat Korespondensi: 2301180253 fanuel@pknstan.ac.id; irwan aribowo@pknstan.ac.id

\section{INFORMASI ARTIKEL}

Diterima Pertama

[24082021]

Dinyatakan Diterima

[15112021]

KATA KUNCI:

kepatuhan pajak, kegiatan pengawasan, wajib pajak strategis

KLASIFIKASI JEL:

$\mathrm{H} 2$

\section{ABSTRAK}

Taxpayer compliance must be concerned about considering the amount of tax contribution to state revenue. This study aims to determine supervision activities of Strategic Taxpayer compliance and the steps that can be done to improve the supervision of Taxpayers compliance in KPP Pratama Sukoharjo. This research used a descriptive approach with qualitative research methods. The data used was primary data related to supervision activities of tax compliance. Supervision activities of Strategic Taxpayer compliance, such as, analysis of financial statements, SP2DK issuance, visitation, warning letters issuance, tax collection letters issuance, and use of the Approweb application. The steps to improve supervision of taxpayer compliance for instance, massive taxation socialization, integration of taxation data, and implementation of specific supervision programs was carried out to face obstacles, challenges, and improve taxpayer compliance.

Kepatuhan Wajib Pajak merupakan hal yang harus diperhatikan mengingat besarnya kontribusi pajak terhadap penerimaan negara. Tujuan penelitian ini untuk mengetahui kegiatan pengawasan kepatuhan Wajib Pajak Strategis dan langkah-langkah yang dapat dilakukan untuk meningkatkan pengawasan kepatuhan perpajakan. Penelitian ini menggunakan pendekatan deskriptif dengan metode penelitian kualitatif. Data yang digunakan adalah data primer terkait kegiatan pengawasan kepatuhan. Kegiatan pengawasan kepatuhan Wajib Pajak Strategis, antara lain, analisis laporan keuangan, penerbitan SP2DK, melaksanakan kunjungan (visit), penerbitan surat teguran, penerbitan surat tagihan pajak, dan penggunaan aplikasi Approweb. Langkah-langkah meningkatkan pengawasan kepatuhan Wajib Pajak berupa sosialisasi perpajakan secara masif, integrasi data perpajakan, dan pelaksanaan program pengawasan khusus dilakukan untuk menghadapi kendala dan tantangan serta meningkatkan kepatuhan Wajib Pajak. 


\section{PENDAHULUAN}

\subsection{Latar Belakang}

Kontribusi penerimaan perpajakan dalam sumber pendapatan negara lebih besar jika dibandingkan dengan hibah dan penerimaan negara bukan pajak. Dalam anggaran pendapatan dan belanja negara (APBN) 2020, pendapatan negara diproyeksikan sebesar Rp2.233,2 triliun yang terdiri atas hibah sebesar Rp0,5 triliun, penerimaan negara bukan pajak sebesar Rp367,0 triliun, dan penerimaan pajak sebesar Rp1.865,7 triliun. Pada tahun 2020, Pandemi Covid-19 menjadi salah satu fenomena besar yang memberikan dampak di berbagai sektor negara Indonesia. Nasution et al. (2020) menyatakan bahwa pandemi Covid-19 memberikan dampak terhadap perekonomian Indonesia dari sisi kegiatan pariwisata, investasi, dan perdagangan. Berdasarkan data Badan Pusat Statistik (BPS), produk domestik bruto (PDB) Indonesia mengalami kontraksi pertumbuhan pada kuartal III-2020 sebesar 3,49 persen. Menurut Blanchard (2009), pertumbuhan PDB yang negatif dapat menjadi indikator bahwa negara tersebut sedang mengalami resesi ekonomi. Dengan demikian, Indonesia mengalami resesi setelah pertumbuhan ekonomi pada kuartal II-2020 mengalami penurunan yang cukup signifikan hingga mencapai minus 5,32 persen. Direktorat Jenderal Pengelolaan Utang (2014) menyatakan bahwa pertumbuhan ekonomi yang rendah menyebabkan menurunnya penerimaan pajak nasional yang akan berdampak pada peningkatan defisit APBN.

Kepatuhan Wajib Pajak perlu dijaga agar penerimaan pajak nasional tidak menurun. Kepatuhan perpajakan dideskripsikan sebagai suatu kondisi yang menggambarkan Wajib Pajak telah menaati semua kewajiban perpajakannya dan memperoleh hak perpajakannya (Nurmantu, 2000). Kepatuhan Wajib Pajak adalah cerminan dari pelaksanaan sistem self assessment. Dalam sistem self assessment, Wajib Pajak memiliki wewenang untuk melakukan sendiri kewajiban perpajakannya, mulai dari menghitung besarnya penghasilan, menghitung besarnya pajak yang terutang, menyetorkan pajak yang terutang, dan menyampaikan pemenuhan kewajiban perpajakannya (Setiyaji \& Amir, 2005). Tingginya kepatuhan pemenuhan kewajiban perpajakan akan berdampak pada meningkatnya penerimaan negara dari sektor perpajakan.

Menurut Zulvina (2011), kepatuhan pemenuhan kewajiban perpajakan dipengaruhi oleh beberapa faktor, yaitu tarif pajak, pemeriksaan pajak, penegakan hukum perpajakan, pelayanan kepada Wajib Pajak, dan kondisi sistem administrasi perpajakan. Di masa pandemi Covid-19 saat ini, upaya meningkatkan kepatuhan Wajib Pajak bukanlah hal mudah sehingga tetap diperlukan tindakan pengawasan terhadap pemenuhan kewajiban perpajakan. Menurut Aribowo dan Zulvina (2017), fase pengawasan dimulai pada saat pemeriksaan pajak atas SPT yang telah dilaporkan oleh Wajib Pajak.
Setiap tahun tercatat peningkatan jumlah Wajib Pajak yang terdaftar dalam sistem administrasi perpajakan. Berdasarkan laporan tahunan DJP, jumlah Wajib Pajak terdaftar secara nasional sebanyak 45,9 juta pada tahun 2019. Jumlah tersebut meningkat sekitar $8,2 \%$ dari tahun sebelumnya. Seiring meningkatnya jumlah Wajib Pajak terdaftar, target penerimaan pajak juga mengalami peningkatan. Peningkatan ini berlaku di Kantor Wilayah DJP (Kanwil DJP) Jawa Tengah II. Target penerimaan pajak di Kanwil DJP Jawa Tengah II pada tahun 2019 sebesar Rp13,9 triliun atau mengalami pertumbuhan sekitar $11,2 \%$ dibanding tahun sebelumnya. Peningkatan jumlah Wajib Pajak terdaftar bukan berarti meningkatkan realisasi penerimaan pajak. Berdasarkan pernyataan Kepala Kanwil DJP Jawa Tengah II, KPP Pratama Sukoharjo menjadi urutan tiga dalam sumber penerimaan pajak terbesar di Kanwil DJP Jawa Tengah II hingga berhasil mencapai Rp1,36 triliun pada tahun 2018 (Ananti, 2019). Namun, realisasi penerimaan pajak tahun 2020 di KPP Pratama Sukoharjo lebih rendah dibanding tahun 2018 dan 2019. Meskipun jumlah Wajib Pajak bertambah setiap tahun, capaian penerimaan pajak di KPP Pratama Sukoharjo mengalami penurunan dari tahun 2018 sampai dengan 2020.

Mulai 16 Maret 2020 sampai 5 April 2020, layanan perpajakan tatap muka di KPP seluruh Indonesia ditutup untuk mencegah persebaran virus Covid-19. Dalam periode tersebut, semua kegiatan di KPP dilakukan secara online sehingga interaksi langsung kepada Wajib Pajak menjadi terbatas. Meskipun sudah diberikan layanan secara online, Wajib Pajak tetap tidak mau mengusahakan kewajiban perpajakannya. Selain itu, informasiinformasi terkait imbauan untuk melaksanakan kewajiban perpajakan telah dipublikasikan melalui media sosial milik KPP Pratama Sukoharjo. Namun, tidak semua Wajib Pajak dapat mengakses informasi tersebut karena tidak memiliki media sosial. Selain pelayanan perpajakan, kegiatan pengawasan kewajiban perpajakan mengalami penyesuaian. Kegiatan pengawasan dilakukan dengan mematuhi protokol kesehatan dan membatasi interaksi dengan Wajib Pajak secara langsung. Dalam rangka pengawasan pajak, KPP Pratama Sukoharjo melakukan komunikasi dan korespondensi dengan Wajib Pajak secara online. Namun, Petugas Pajak dan Wajib Pajak belum familiar dengan penggunaan video conference dalam berkomunikasi untuk melakukan klarifikasi data perpajakan. Berdasarkan uraian diatas, tujuan penelitian ini untuk mengetahui kegiatan pengawasan kepatuhan Wajib Pajak Strategis dan langkah-langkah yang dapat dilakukan untuk meningkatkan pengawasan kepatuhan perpajakan.

\section{KERANGKA TEORI}

\subsection{Sistem Pemungutan Pajak}

Menurut Mardiasmo (2009), sistem pemungutan pajak yang berlaku di Indonesia dibagi menjadi tiga, yaitu: 
a. Self Assessment System

Sistem pemajakan yang memberi hak kepada Wajib Pajak untuk menetapkan besarnya pajak terutang. Dalam sistem ini, Wajib Pajak secara aktif menghitung, menyetorkan, dan melaporkan sendiri pajak yang terutang, sedangkan Petugas Pajak hanya sebagai pengawas pajak.

b. Official Assessment System

Sistem pemajakan yang memberi hak kepada Petugas Pajak untuk menghitung besarnya pajak terutang oleh Wajib Pajak. Utang pajak timbul setelah otoritas pajak mengeluarkan surat ketetapan pajak.

c. Withholding System

Sistem pemajakan yang memberi hak kepada pihak ketiga (bukan Wajib Pajak dan Petugas Pajak yang bersangkutan) untuk menetapkan besarnya pajak terutang oleh Wajib Pajak.

\subsection{Kepatuhan}

Menurut Kamus Besar Bahasa Indonesia, kata "patuh" memiliki arti taat (pada aturan, perintah, dan sebagainya), suka menurut (perintah dan sebagainya), dan disiplin. Dengan demikian, kepatuhan perpajakan berarti ketaatan Wajib Pajak dalam menjalankan kewajiban perpajakannya sesuai dengan ketentuan perundang-undangan perpajakan yang berlaku. Berikut definisi kepatuhan perpajakan menurut para ahli:

a. Menurut Nurmantu (2000), kepatuhan perpajakan adalah kondisi yang menggambarkan Wajib Pajak telah menaati semua kewajiban perpajakan dan memperoleh hak perpajakannnya.

b. Kepatuhan perpajakan menurut Gunadi (2005) adalah kemauan Wajib Pajak untuk menaati kewajiban pajaknya tanpa dilakukan peringatan, investigasi seksama, pemeriksaan, ataupun penerapan sanksi dan ancaman.

c. Norman D. Nowak (n.d., dikutip dalam Rahayu, 2010) menjelaskan bahwa kepatuhan perpajakan tercermin ketika Wajib Pajak mengerti semua ketentuan peraturan perpajakan, menghitung dengan benar besarnya pajak, melengkapi formulir pajak dengan jelas dan lengkap, serta menyetorkan pajak tepat waktu.

Adapun jenis-jenis kepatuhan Wajib Pajak menurut Rahayu (2010), yaitu:

a. Kepatuhan formal

Wajib pajak menaati kewajiban secara formal sesuai dengan ketentuan perundang-undangan perpajakan. Contohnya wajib pajak melaporkan Surat Pemberitahuan (SPT) Tahunan Pajak Penghasilan sebelum berakhirnya jatuh tempo pelaporan.

b. Kepatuhan material

Wajib pajak secara substantif menaati ketentuan material perpajakan, yaitu sesuai jiwa dan isi undang-undang perpajakan. Kepatuhan material bisa mencakup kepatuhan formal.
Contohnya wajib pajak mengisi SPT Tahunan Pajak Penghasilan dengan jelas, lengkap, dan benar kemudian menyampaikan SPT tersebut tepat waktu

\subsection{Wajib Pajak Strategis}

Wajib Pajak yaitu badan atau orang pribadi yang ditentukan oleh aturan perpajakan untuk memenuhi kewajiban perpajakannya (Suandy, 2002). Berdasarkan Surat Edaran Direktur Jenderal Pajak Nomor SE-07/PJ/2020, Wajib Pajak dibagi menjadi dua, yaitu:

a. Wajib Pajak Strategis

Wajib Pajak dengan kontribusi penerimaan pajak terbesar atau tolok ukur lainnya yang terdaftar di KPP Pratama dan seluruh Wajib Pajak yang terdaftar pada KPP di lingkungan Kanwil DJP Jakarta Khusus, KPP di lingkungan Kanwil DJP Wajib Pajak Besar, dan KPP Madya.

b. Wajib Pajak Lainnya.

Wajib Pajak pada KPP Pratama selain Wajib Pajak Strategis, baik yang belum memiliki NPWP maupun yang telah memiliki NPWP.

\subsection{Pengawasan}

Pengawasan menurut Siagian (1989) adalah proses mengamati pengoperasian seluruh aktivitas organisasi untuk memastikan supaya kegiatan yang sedang dilaksanakan dapat berjalan sesuai prosedur yang telah ditetapkan. Fase pengawasan Wajib Pajak dimulai pada saat pemeriksaan atas SPT yang telah dilaporkan Wajib Pajak (Aribowo dan Zulvina, 2017). Sovita dan Salsabilla (2018) menerangkan fungsi pengawasan Wajib Pajak untuk memonitor dan mengingatkan kewajiban perpajakan Wajib Pajak sesuai dengan peraturan dan undang-undang perpajakan yang berlaku.

Berdasarkan Surat Edaran Direktur Jenderal Pajak Nomor SE-07/PJ/2020, kegiatan pengawasan dan pemeriksaan Wajib Pajak Strategis diawali dengan melaksanakan penelitian secara komprehensif untuk tahun pajak sebelum tahun pajak berjalan dan untuk tahun pajak berjalan. Penelitian untuk tahun pajak berjalan dilakukan sesuai dengan SE-14/PJ/2018 tentang Pengawasan Wajib Pajak Pasca Periode Pengampunan Pajak (SE14/2018), SE-49/PJ/2016 tentang Pengawasan Wajib Pajak Melalui Sistem Informasi (SE-49/2016), dan/atau SE-39/PJ/2015 tentang Pengawasan Wajib Pajak dalam Bentuk Permintaan Penjelasan atas Data dan/atau Keterangan, dan Kunjungan (Visit) Kepada Wajib Pajak (SE-39/2015). Berdasarkan Keputusan Direktur Jenderal Pajak Nomor KEP-75/PJ/2020, Wajib Pajak Strategis diawasi oleh Account Representative Seksi Pengawasan dan Konsultasi II.

\section{METODE PENELITIAN}

Penulis menggunakan pendekatan deskriptif dengan metode penelitian kualitatif. Pendekatan deskriptif merupakan penelitian yang bertujuan untuk memperoleh konsep secara terstruktur mengenai peristiwa atau situasi yang terjadi 
(Saunders et al., 2019). Penelitian kualitatif menurut Anggito dan Setiawan (2018) adalah pengumpulan data pada suatu kejadian ilmiah untuk menafsirkan fenomena yang terjadi dengan memposisikan peneliti sebagai instrumen kunci.

\subsection{Kajian Pustaka}

Metode ini dilakukan dengan menghimpun informasi dan data yang berhubungan dengan topik penelitian untuk dijadikan sebagai dasar teoritis dalam membahas permasalahan yang diangkat pada penelitian ini. Penulis mengumpulkan informasi dan data dari beragam literatur, seperti buku-buku perkuliahan, Undang-Undang Perpajakan, Peraturan Menteri Keuangan, Peraturan Direktur Jenderal Perpajakan, jurnal perpajakan, dan website yang terpercaya.

\subsection{Penelitian Lapangan}

Penulis mengajukan permintaan data secara langsung ke KPP Pratama Sukoharjo berkaitan dengan topik yang diangkat. Pegumpulan data dan informasi dalam metode ini dilakukan dengan cara sebagai berikut:

1. Teknik Wawancara

Metode ini dilaksanakan melalui tanya jawab dengan AR seksi Pengawasan dan Konsultasi II di KPP Pratama Sukoharjo untuk mendapatkan informasi yang relevan dan tepat.

2. Teknik Dokumentasi

Teknik ini dilakukan dengan mengumpulkan dokumen pemerintah sebagai penunjang penelitian, yaitu berupa data-data terkait sebaran Wajib Pajak dan capaian penerimaan pajak di KPP Pratama Sukoharjo serta pemenuhan kewajiban penyetoran pajak dan penyampaian SPT Tahunan Wajib Pajak Strategis yang diperoleh dari KPP Pratama Sukoharjo.

\section{HASIL PENELITIAN}

\subsection{Kegiatan Pengawasan Kepatuhan Wajib Pajak Strategis}

Pengawasan kepatuhan kewajiban perpajakan Wajib Pajak Strategis merupakan salah satu tugas AR seksi Pengawasan dan Konsultasi II. Kegiatan pengawasan, baik kepatuhan formal maupun kepatuhan material, dilakukan terhadap seluruh Wajib Pajak Strategis yang menjadi tanggung jawab setiap Account Representative. Berdasarkan wawancara kepada dua narasumber dengan jabatan Account Representative seksi Pengawasan dan Konsultasi II, jumlah Wajib Pajak Strategis yang diawasi saat ini oleh Narasumber I sebanyak 54 Wajib Pajak Strategis dan Narasumber II sebanyak 52 Wajib Pajak Strategis. Pengawasan kepatuhan secara menyeluruh dapat dilakukan karena jumlah Wajib Pajak Strategis yang diawasi Account Representative relatif sedikit.

Kegiatan pengawasan terhadap pemenuhan kewajiban perpajakan Wajib Pajak Strategis meliputi pengawasan tahun pajak berjalan dan pengawasan sebelum tahun pajak berjalan. Berdasarkan hasil wawancara dengan Narasumber II, pengawasan kepatuhan Wajib Pajak Strategis untuk tahun pajak berjalan dilakukan dengan mengawasi penyetoran pajak dan penyampaian SPT, baik SPT Masa maupun SPT Tahunan, serta pemberian sanksi terkait ketidakpatuhan dengan menerbitkan Surat Tagihan Pajak. Pengawasan Wajib Pajak Strategis untuk sebelum tahun berjalan dilakukan dengan meneliti kepatuhan materialnya, seperti analisis kebenaran isi SPT yang dilaporkan Wajib Pajak Strategis terhadap data eksternal dan internal yang dimiliki KPP.

Terdapat dasar hukum khusus yang diterapkan dalam kegiatan pengawasan kepatuhan Wajib Pajak Strategis, yaitu SE-39/2015, SE-49/2016, dan SE$14 / 2018$. Bentuk kegiatan pengawasan kepatuhan Wajib Pajak Strategis yang dilakukan oleh Account Representative di KPP Pratama Sukoharjo, antara lain, analisis laporan keuangan untuk mamantau kepatuhan material wajib pajak strategis, penerbitan SP2DK untuk meminta klarifikasi kepada wajib pajak atas data-data yang dilaporkan, kunjungan (visit) untuk melakukan pemutakhiran data perpajakan, penerbitan surat teguran untuk mengingatkan wajib pajak agar segera melaksanakan kewajiban perpajakannya, penerbitan Surat Tagihan Pajak apabila wajib pajak tidak patuh dalam melaksanakan kewajiban perpajakannya, dan penggunaan aplikasi Approweb untuk melakukan pengawasan kepatuhan dan penggalian potensi pajak melalui modul-modul yang tersedia dalam aplikasi tersebut

\subsection{Langkah-Langkah Meningkatkan Pengawasan Kepatuhan Wajib Pajak Strategis}

Inovasi kegiatan pengawasan penting untuk dilakukan dalam rangka meningkatkan kepatuhan pemenuhan kewajiban perpajakan Wajib Pajak. Inovasi juga diperlukan untuk menghadapi kendala dan tantangan dalam pelaksanaan kegiatan pengawasan. Berdasarkan wawancara kepada dua narasumber dengan jabatan AR seksi Pengawasan dan Konsultasi II, langkah-langkah meningkatkan pengawasan kepatuhan pemenuhan kewajiban perpajakan sebagai berikut.

a. Sosialisasi Perpajakan Secara Masif

Berdasarkan hasil wawancara dengan

Narasumber I, Wajib Pajak Strategis diasumsikan sudah mengetahui peraturan perpajakan. Namun, sosialisasi perpajakan yang masif tetap dilakukan sebagai bentuk kegiatan pengawasan untuk mengingatkan Wajib Pajak Strategis agar memenuhi kewajiban perpajakannya. Sosialisasi perpajakan tersebut, antara lain, pemberian surat himbauan dan seruan melalui media massa.

b. Integrasi Data Perpajakan

Integrasi data perpajakan adalah proses penggabungan data Wajib Pajak dengan bantuan sistem informasi dan teknologi ke basis data perpajakan DJP. Tujuan mengintegrasikan data dalam suatu sistem untuk menghasilkan data yang komprehensif dan valid dalam rangka pemantauan kepatuhan tahun pajak berjalan 
dan sebelum tahun pajak berjalan. Integrasi data akan memudahkan DJP dalam mengawasi pemenuhan kewajiban perpajakan. Hal ini sejalan dengan hasil wawancara dengan Narasumber II bahwa sistem data yang terintegrasi menjadi bahan baku Account Representative untuk meneliti dan menguji validitas data pelaporan dan pembayaran yang sudah dilakukan Wajib Pajak dengan basis data DJP.

c. Pelaksanaan Program Pengawasan Khusus Kegiatan pengawasan dapat berjalan optimal dan efektif melalui perencanaan program pengawasan yang matang. Berdasarkan hasil wawancara dengan Narasumber II, DJP sedang mengembangkan program-program pengawasan khusus, antara lain, pengawasan Wajib Pajak Prominen dan penanganan Wajib Pajak dengan transfer pricing. Program pengawasan Wajib Pajak Prominen adalah kegiatan pengawasan terhadap segmen Wajib Pajak dengan status kepemilikan kekayaan atau omzet yang besar, sedangkan program penanganan Wajib Pajak dengan transfer pricing adalah kegiatan pengawasan terhadap Wajib Pajak yang memiliki transaksi afiliasi dan berisiko tinggi melakukan transfer pricing. Wajib Pajak Strategis sebagai wajib pajak dengan kontribusi penerimaan pajak terbesar di KPP Pratama dapat digolongkan dalam program pengawasan khusus tersebut. Dengan demikian, program pengawasan khusus tersebut dapat meningkatkan kepatuhan pemenuhan kewajiban perpajakan Wajib Pajak Strategis.

\section{KESIMPULAN}

\subsection{Kegiatan Pengawasan Kepatuhan Wajib Pajak Strategis}

Seksi Pengawasan dan Konsultasi II bertugas melaksanakan kegiatan pengawasan pemenuhan kewajiban perpajakan Wajib Pajak Strategis. Kegiatan pengawasan kepatuhan Wajib Pajak Strategis, baik kepatuhan formal maupun kepatuhan material, dilakukan secara menyeluruh karena jumlah wajib pajak yang diawasi oleh setiap Account Representative relatif sedikit. Kegiatan pengawasan kepatuhan Wajib Pajak Strategis meliputi pengawasan tahun pajak berjalan dan pengawasan sebelum tahun pajak berjalan. Bentuk kegiatan pengawasan kepatuhan Wajib Pajak Strategis yang dilakukan oleh Account Representative di KPP Pratama Sukoharjo, antara lain, analisis laporan keuangan, penerbitan SP2DK, melaksanakan kunjungan (visit), penerbitan surat teguran, penerbitan Surat Tagihan Pajak, dan penggunaan aplikasi Approweb.

\subsection{Langkah-Langkah Meningkatkan Pengawasan Kepatuhan Wajib Pajak Strategis}

Langkah-langkah meningkatkan kegiatan pengawasan kepatuhan dilakukan oleh Account Representative untuk menghadapi kendala dan tantangan yang terjadi serta meningkatkan kepatuhan pemenuhan kewajiban perpajakan Wajib Pajak. Langkah langkah meningkatkan kegiatan pengawasan kepatuhan Wajib Pajak, antara lain, sosialisasi perpajakan secara masif, integrasi data perpajakan, dan melaksanakan program pengawasan khusus. Sosialisasi perpajakan dilakukan oleh Account Representative dengan pemberian surat himbauan dan seruan melalui media massa untuk mengingatkan Wajib Pajak agar segera memenuhi kewajiban perpajakannya. Integrasi data perpajakan digunakan oleh Account Representative untuk memantau kepatuhan Wajib Pajak tahun pajak berjalan dan sebelum tahun pajak berjalan melalui penelitian dan pengujian validitas data yang telah dilaporkan Wajib Pajak dengan basis data perpajakan DJP. Pelaksanaan program pengawasan khusus dilakukan oleh AR terhadap Wajib Pajak yang memenuhi kriteria tertentu untuk dijadikan prioritas pengawasan agar kegiatan pengawasan berjalan optimal dan efektif serta kepatuhan pemenuhan kewajiban perpajakan Wajib Pajak meningkat.

\section{IMPLIKASI DAN KETERBATASAN}

Hasil penelitian ini menunjukkan implikasi dari kegiatan pengawasan adalah peningkatan kepatuhan Wajib Pajak yang dapat menyebabkan penerimaan pajak meningkat. Keterbatasan literatur dan pengetahuan penulis mengakibatkan tulisan ini masih membutuhkan kajian yang lebih dalam. Penelitian ini diharapkan dapat menjadi pertimbangan bagi KPP Pratama dalam meningkatkan kegiatan pengawasan kepatuhan perpajakan.

\section{DAFTAR PUSTAKA (REFERENCES)}

Ananti, R. (2019). Penerimaan pajak DJP Jateng II capai Rp 2,1 triliun. Diakses tanggal 13 Mei 2021, dari http://www.klinikpajak.co.id

Anggito, A., \& Setiawan, J. (2018). Metodologi penelitian kualitatif. CV Jejak.

Aribowo, I., \& Zulvina, S. (2017). Bahan ajar KUP (Ketentuan Umum dan Tata Cara Perpajakan). Politeknik Keuangan Negara STAN.

Blanchard, O. (2009). Macroeconomics (5th Edition). Prentice Hall.

Direktorat Jenderal Pengelolaan Utang. (2014). Laporan analisis portofolio dan resiko utang 2013.

Gunadi. (2005). Fungsi pemeriksaan terhadap peningkatan kepatuhan wajib pajak (tax compliance). Jurnal Perpajakan Indonesia, 4(5), 4-9.

Mardiasmo. (2009). Perpajakan. Salemba Empat.

Nasution, D. A. D., Erlina, \& Iskandar, M. (2020). Dampak pandemi Covid-19 terhadap perekonomian Indonesia. Jurnal Benefita, 5(2), 212-224.

Nurmantu. (2000). Dasar-dasar perpajakan. Ind-HillCo. 
Rahayu, S. K. (2010). Perpajakan teori dan teknis perhitungan. Graha IImu.

Saunders, M. N. K., Lewis, P., \& Thornhill, A. (2019). Research methods for business students. Pearson.

Setiyaji, G., \& Amir, H. (2005). Evaluasi kinerja sistem perpajakan Indonesia. Jurnal Ekonomi.

Siagian, S. P. (1989). Filsafat administrasi. Gunung Agung.

Sovita, I., \& Salsabilla, A. (2018). Pengaruh peran account representative terhadap tingkat kepatuhan wajib pajak orang pribadi (studi kasus pada Kantor Pelayanan Pajak Pratama Padang Satu). Jurnal Ekonomi \& Bisnis Dharma Andalas, 20(2), 261.

Suandy, E. (2002). Perpajakan. Salemba Empat.

Zulvina, S. (2011). Bahan ajar pengantar hukum pajak. Sekolah Tinggi Akuntansi Negara. 